\title{
Implementation of Al-Wadiah (saving instrument) Contract in Contemporary Gold Transaction
}

\author{
Mohd Sollehudin Shuiba ${ }^{a^{*}}$, Azizi A. Bakara, Amirul F. Osmana, Hydzulkifli Hashimª, Aiman bin Fadzila \\ a Islamic Business School, College of Business, Universiti Utara Malaysia, Sintok, Kedah, Malaysia. \\ ${ }^{*}$ Corresponding author's email address: sollehudin@uum.edu.my
}

\section{A R T I C L E I N F O}

Received: 23-07-2016

Accepted: 16-08-2016

Available online: 29-09-2016

Keywords:

Gold Transaction;

Islamic Law of Contract;

Wadiah Contract

JEL Classification:

F23, G10, G21,

\begin{abstract}
A B S T R A C T
Contemporary gold trading is like other retails and online trading. However, according to Islamic business contract, gold is categorized under a special law of transaction items and it must follows a specific law of Islamic business transaction. This article focuses on how wadiah concepts can be applied in the contemporary gold trading. The legality of the wadiah concepts is utmost important to be verified before its implementation. The aims of this article is to substantiate the concepts of wadiah in contemporary gold trading based on the main sources of Islamic law transactions. The finding shows that the wadiah concept is permissible in Islam. Furthermore, the wadiah also play important role in contemporary gold trading. Hence, wadiah contract can helps to resolve the gold trading issues where the physical assets of gold are distance from the buyer.
\end{abstract}

This is an open access article under the terms of the Creative Commons Attribution License 4.0, which allows use, distribution and reproduction in any medium, provided the original work is properly cited.
ISSN 2380-4041(Print), ISSN 2380-405X(Online)

\subsection{Introduction}

Wadiah in Islam refer to a concept of keeping and saving or hold something for a certain period of time. The term wadiah is derived from the verb wada'a, which means to leave, lodge or deposit (Al-Farabi, 1987). Legally, the Islamic scholars define wadiah as an empowerment to someone for keeping the owner's property explicitly and implicitly, presentation in keeping possession of respectable private goods in specific way or representation in keeping (other's property) and it is done (by the keeper) as charity (ISRA, 2012; Qaed, 2014).

Legality in Islamic law of contract is very important. Sources of legality normally will refer to main sources of Islam law and second sources of Islamic law. Main sources of Islamic law is Quran and Sunnah, then follow by second sources like qiyas, istihsan, masalih mursalah and more. Legality for wadiah refer to al-Quran Surah alNisa' verse 48:" Indeed, Allah commands you to render trust to whom they are due and when you judge between people, to judge with justice". Another evidence also from al-Quran Surah al-Baqarah verse 283 means:" If you trust one another, then let him who is trusted fulfil his trust, and let him be conscious of God, his sustaine". This evidence from Quran story on how trust concept deeply very important in Islam way of life. Man must fullfill his trust and man must render trust when judge between two people.

Pillars is very important in Islamic law of business contract. All party in the contract require to fulfill the pillars to make sure the contract become binding and acceptable. Pillars for wadiah (deposit) (Qaed, 2014):

a. Contracting parties: the depositor and the custodian must be person of sound mind. 
b. The depositor is able to the take the property whenever he wants.

c. Offer (ijab) and acceptance (qabul): the majority of jurists are the view there is must be a valid offer and acceptance made in wadiah contract

d. Deposited property: it must be owned and deliverable. The item must be also form of property that can be physically possessed (ISRA, 2012).

Example how to fulfill the pillars in wadiah, like Ahmad save his money at Islamic bank use wadiah deposit account. Ahmad be a depositor, while Islamic bank is custodian. Ahmad able to withdraw his money from custodian whenever he want. They also must be offer and acceptance between Ahmad and Islamic bank to create wadiah agreement (wadiah ontract). Another example is, Mikhail ask Raimi to keep his car for a week. This is due to Mikhail need to go outstation. Mikhail become depositor, Raimi become custodian, offer and acceptance happen between Raimi nad Mikhail. Agreement between Mikhail and Raimi about to keep the car for a week. The custodian under wadiah contract permissible to charge some amount for their service based on agreement between them.

\subsection{Contemporary gold trading}

Gold have unique functions, portable, divisible, indestructible, scarce and cannot creatively be produced (Hafizi, et al., 2016). Gold known as an ideal value keeper of which it can be kept for future use and will not be obsolete like fiat money (Syed Alwi et al., 2013). Gold bullion show support for the safe haven property (Pullen at al, 2014). Gold also will be good saving mekanisme in downturn or economic crysis situation. In 1997/98, East Asian country face financial economic crisis (Zhang, 1998; Cao, 1999). Gold also acceptable worldwide and easily recognize as a payment form. Demand of gold comes from many segments namely from its consumers in the form of jewellery, from industry as gold is an excellent conductor of electricity (World Gold Council, 2011).

Muamalat Islam (Islamic law of contract) known gold as jewellery (for women), something that with high valued and become money in certain period of Islamic history. Not like the other items or product, gold categorize one of six ribawi item. Ribawi item means that items with special rule of transaction. Items that not included under ribawi item, we can transact it through cash, by loan and leasing. But rule transaction for ribawi item based on muamalat Islam must be in cash and on the spot (Islamic Finance News, 2016) delivery. That's means gold transaction are not acceptable if payment not in cash and delayed delivery. If gold trade with gold must be equal like 100gram gold with 100gram gold (Security Commission, 2014). According to Habib Ahmed, Riba (interest) of delay or credit Riba prohibits sale of commodities in the future even if the counter-values are equal (Islamic Finance News, 2016).

The rule of Six ribawi items transactions based on Hadith by Muslim is: "Gold is to be paid for by gold, silver by silver, wheat by wheat, barley by barley, dates by dates, and salt by salt - like for like, equal for equal, payment being made on the spot. If the species differ, sell as you wish provided that payment is made on the spot". Hadith : Muslim no 1587 (web Islamic Finance News, 2016). Based on the hadith, any transaction use this six ribawi items must be in cash and on the spot delivery. If muslim buy a gold, silver, wheat, barley, dates and salt, must be in cash and on the spot delivery to make sure approved contract. If we void on cash part or on the spot delivery part, the contract are not approved or not acceptable based on Islamic law of contract. Islamic finance thinker believe that interest-based financing leads to a false economy, creating instability, inflation, unemployment, and cyclical crashes (Islamic Finance News, 2016).

Nowadays, awareness people in gold or to buy gold in Malaysia are more and high than before. This is due to more campaign on saving gold, more product and good in demand power. Types of gold products in market is gold investment accounical that offer by Islamic bank (KFHMB, 2016) and conventional bank (Maybank, 2016), trading physical gold like offer by Bank Negara Malaysia (www.bnm.gov.my, 2016) and buy gold through online transaction.

Some product of gold in Malaysia nowadays offer transantion through online. That's mean, we buy a gold, pay online (in cash) and waiting for certain period (not on the spot delivery). This online style of gold transaction is fulfill rule of Islamic law of contract due to delayed in delivery gold (ribawi items). So how to solve this problem? One of the idea can be extend for discussion, using wadiah contract will void party from issue of delayed in delivery of gold. Delayed may happen due to the party involve in buy and sell gold stay far each other. Wadiah in gold transaction happen when one party ask another party to buy a gold or physical gold from him. Example in practice is Mahmud ask Zain to buy a gold at Singapore. This is due to Mahmud at Kuala Lumpur and Zain at Singapore. This transaction involved 25gram of gold. Mahmud transfer the amount of money to Zain like RM5000. Then Zain after foreign exchange process, will buy the gold for Mahmud. Zain will buy it from another party or jewelleries shop at Singapore. Mahmud promise to go and take the gold from Zain after one week. So for 
the period of waiting one week, Zain will keep the gold with him. Under muamalat rule, wadiah can be used for process of keeping that gold. That's mean Mahmud agree with Zain to use and follow wadiah contract for keeping that gold for a week.

Based on wadiah pillars, Mahmud will be the depositor and Zain will be the custodian. The deposit is 25 gram of gold (maybe coin, maybe jewellery). Offer and acceptance under wadiah contract will do by Mahmud and Zain. Offer and acceptance can do through writing agreement, verbal or any any communication that can understand by both party. Mahmud can go and take the gold when complete one week of before it due to under wadiah depositer can withdraw whenever he want. Zain also can charge Mahmud for keeping service based on agreed by both party in early agreement. Wadiah between Mahmud and Zain will finish when Mahmud withdraw all 25 gram of that gold. Using muamalat contract like wadiah at least will make muslim far from involved in uncertainty contract. This is due to Mikhail and gold seller clearly done their transaction based on Islamic law of contract.

\subsection{Conclusion}

Islamic law of contract offers a lot of instrument to be practice in Islamic finance and banking industry and any trading and transaction related. Wadiah (safekeeping contract) can play an important role to make sure all the transaction compliance with syariah (Islamic law). As discussion in this article, wadiah practice can help people far from interest transaction when involved in ribawi items trading. As discussed in this article, wadiah practices can avoid any interest (riba) immersion in gold trading as a gold is a ribawi items which must follows a very strict condition.

Gold is one of the ribawi items and people always give high intention on gold trading. Using wadiah, can help muslim to ensure that their ribawi items transaction is shariah compliance. It will helps muslim to buy gold or ribawi items if the items are not at their close custody, for example, are kept at $500 \mathrm{~km}$ away. Islamic law of contract guide us to trade according to shariah. All these efforts will help trade, investor, community at large, economic growth and most importance; blessing from Almighty God.

\section{Acknowledgement}

This research was supported in part by a Fundamental Research GrantScheme (FRGS) (s/o code. 12939) Minister of Higher Education, Malaysia.

\section{References}

Al-Farabi, A.N.I.B.H 1987. Al Shahah Taju Al Lughah Al Shahah Al Arabiyah. BeirutDar El Ilm

Bank Negara Malaysia. (2015). Wakalah Concept Paper, Kuala Lumpur: BNM, derived from http://www.bnm.gov.my/guidelines/05_shariah/Wakalah.pdf

Bank Negara Malaysia. (2016). Kijang Emas, http://www.bnm.gov.my/index.php?ch=statistic\&pg=statistic kijangemas

Cao, F., (1999). The Asian Financial Crisis and Chinese Currency, Information Journal, Vol.2, No.3, July 1999, derived from http://www.information-iii.org/abs_e.html\#No3-1999

Furqani, H., (2013), Fatwa in Islamic Finance Bulletin, Kuala Lumpur: ISRA

Hafizi A.M., Halid, N., Aziz, N. A., and Janor. H., (2016). 'Gold Investment in Malaysia: Its Operation, Contemporary Applications and Shariah Issues'. Derived from conference.qfis.edu.qa/app/media/7026.

Islamic Finance news. (2016). All that glitters: What impact could gold really have on Islamic finance?'. Derived from http://www.islamicfinancenews.com/glossary/ribawi

International Shari'ah Research Academy for Islamic Finance (2012), Islamic Finacial System; Principle \& Oparations. Kuala Lumpur: International Shari'ah Research Academy for Islamic Finance (ISRA)

KFHMB. (2016). Gold Account-I,

Maybank. (2016). Gold Investment Account Products,

Noor, A.M., (2013). Wakalah Paper, derived from drazman.net/wp-content/uploads/2013/03/wakalahpaper.pdf.

NuHtay, S. N., \& Salman, S.A., (2013). Shari'ah and Ethical Issue in the Practice of Modified Wakalah Model in Family Takaful, International Journal of Business and Social Science, vol. 4 no. 12, September 2013.

Online Dictonary (2016), https://www.google.com/search?q=meaning+of+gold\&ie=utf-8\&oe=utf-8

Pullen, T., Benson, K., and Faff, R., (2014). A Comparative Analysis of the Investment Characteristics of Alternative Gold Assets, A Journal of Accounting, Finance and Business Studies (ABACUS), Vo. 50, No. 1, 2014 
Qaed, I.Q.m., (2014), The Concept of Wadiah and its application in Islamic Banking, Journal of Research in Humanities and Social Science Volume 2, Issue 11 (2014) pp: 70-74.

Ryu, S., and Won, J., (2015). The Global Financial Crises and Intermediation Efficiency in the Korean Banking Sector, Information Journal, Vol.19, No. 6(A), June, 2016. Derived from http://www.informationiii.org/abs_e2.html\#No12-2015

Saleem, M.Y., (2015). Islamic Commercial Law', John Wiley \& Sons: NJ USA

Security Comission. (2014). Shariah Parameters on Islamic Exchange-Traded Fund Based on Gold and Silver. Derived from http://www.sc.com.my/wp-content/uploads/eng/html/icm/Shariah_Parameters_70ctober 14.pdf

Syed Alwi, S.F., Suhaimi, M. \& Mohamed Kamil, M. M. (2013). Gold Investment Account in Kuwait Finance House (M) Berhad and Maybank Berhad, Journal of al-Thaqafah, vol. 3 issue 1, KUISAS: Ipoh

Web Islamic Finance. (2016). http://www.islamic-finance.com/item_sarf_f.htm. Please also refer to Hadith Collection by Imam Muslim (primary sources).

World Gold Council (2011), 'Liquidity in the Global Gold Market', WGC: United Kingdom

Zhang, D., (1998). The Impact of the East Asian Financial Crisis on China's Economy, Information Journal, Vol.1, No.1, July, 1998. Derived from http://www.information-iii.org/abs_e.html\#No1-1998

Web link

http://www.kfh.com.my/kfhmb/v2/contentView.do?contentTypeId=3000\&displayPage=\%2Fver2\%2Fcontent \%2Fstandard.jsp\&channelPath=\%2Fver2\%2Fv2_Navigation\%2FCommercial+Banking\%2FInvestments\& programName $=04 \_$Gold + Account $\&$ tabId $=1 \&$ cntName $=01-$ GoldAccount-i

http://www.maybank2u.com.my/mbb_info/m2u/public/personalDetail04.do?channelId=INVInvestment\&cntTypeId $=0 \&$ cntKey $=I N V 03.02 \&$ programId $=I N V 03-G o l d \&$ chCatId $=/ \mathrm{mbb} /$ Personal $/ \mathrm{INV}$ Investment 